\title{
Extended-spectrum
}

\section{beta-lactamase-producing Pseudomonas aeruginosa in camel in Egypt: potential human hazard}

\author{
Mahmoud Elhariri ${ }^{1}$, Dalia Hamza ${ }^{2 *}$, Rehab Elhelw ${ }^{1}$ and Sohad M. Dorgham ${ }^{3}$
}

\begin{abstract}
Background: The rapid increase of extended-spectrum beta-lactamase (ESBL) producing bacteria are a potential health hazard. Development of antimicrobial resistance in animal pathogens has serious implications for human health, especially when such strains could be transmitted to human. In this study, the antimicrobial resistance due to ESBL producing Pseudomonas aeruginosa in the camel meat was investigated.

Methods: In this study meat samples from 200 healthy camels at two major abattoirs in Egypt (Cairo and Giza) were collected. Following culture on cetrimide agar, suspected P. aeruginosa colonies were confirmed with a Vitek 2 system (bioMe'rieux). P. aeruginosa isolates were phenotypically identified as ESBL by double disk synergy test. Additionally antimicrobial susceptibility testing of ESBL producing P. aeruginosa isolates were done against 11 antimicrobial drugs and carried out by disk diffusion method. The ESBL genotypes were determined by polymerase chain reaction according to the presence of the bla $a_{\text {PER-1 }}, b / a_{C T X-M}, b / a_{\text {SHV }}$ and bla $a_{\text {TEM }}$.

Results: Pseudomonas aeruginosa was isolated from 45 camel meat sample (22.5\%). The total percentage of ESBL producing P. aeruginosa was 45\% (21/45) from camel meat isolates. Antibiogram results revealed the highest resistance was for $c$, ceftriaxone and rifampicin followed by cefepime and aztreonam. The prevalence rates of $\beta$-lactamase genes were recorded (bla $a_{\text {PER-1 }} 28.5 \%$, bla $a_{\text {CTX-M }} 38 \%$, bla $a_{\text {SHV }} 33.3 \%$ and bla $\left.a_{\text {TEM }} 23.8 \%\right)$.

Conclusions: This study illustrates the presence of high rates of ESBL-P. aeruginosa in camels that represents an increasing alarming for the risk of transmission to human and opens the door for current and future antibiotics therapy failure. Livestock associated ESBL-P. aeruginosa is a growing disaster, therefore, attention has to be fully given to livestock associated ESBL-bacteria which try to find its way to human beings.
\end{abstract}

Keywords: Camel, ESBL, P. aeruginosa, Resistance genes, Livestock, Egypt

\section{Background}

The increasing resistance of potentially pathogenic bacteria to multiple conventional antibiotics is an urgent problem in global public health [1]. Pseudomonas aeruginosa is one of the major causes of diseases such as otitis, mastitis, endometritis, hemorrhagic pneumonia and urinary

*Correspondence: daliahamza@cu.edu.eg

${ }^{2}$ Department of Zoonoses, Faculty of Veterinary Medicine, Cairo

University, PO Box 12211, Giza, Egypt

Full list of author information is available at the end of the article tract infections in both livestock and companion animals [2-4]. The multiple-drug-resistant (MDR) Pseudomonas can be transmitted from different sources to humans and also to the environment through horizontal gene, the emergence and occurrence of MDR P. aeruginosa strains are growing in the world, leading to limited therapeutic options $[5,6]$.

The prevalence of MDR enterobacteriaceae in slaughterhouses, including swine and poultry environments, has been reported in several studies building a growing alarm about their effect on animal and human health 
$[7,8]$. Recently encountered the emergence of livestock associated ESBL-producing $P$. aeruginosa in cow, poultry and pigs $[9,10]$.

In Middle East region, camels are important in the livestock economy by their adaptability to adverse environmental conditions and naturally resistant to most of the diseases commonly affecting livestock [11]. Camels provide milk, meat, wool, hides, and skin, and their dung is used for fires [12]. They are acting one of major and good sources of protein and income for developing countries.

Transmission of ESBL-producing gram-negative bacteria between food-producing animals and humans via direct contact or meat is supposed [13]. Accordingly, livestock associated ESBL-producing gram-negative bacteria become new alarm for emerging infectious pathogens to human and animals.

This study aimed to investigate the role of camels as a risky reservoir and disseminating carrier of ESBL producing $P$. aeruginosa especially as this micro-organism has the ability of producing multidrug resistant enzymes that could be easily disseminated in the community via livestock products, particularly through direct contact and/or consumption of meat as well as other infected animal products.

\section{Methods}

\section{Camel meat samples}

This study was carried out on 200 apparently healthy camels. These camels were selected from two major abattoirs (Cairo and Giza) from April to September 2015. Meat samples from slaughtered camels in the abattoirs were collected in sterile containers and sent on ice to the microbiology department laboratory.

\section{Meat samples preparation}

Twenty-five grams of the collected meat samples were weighed and transferred to sterile flasks containing $100 \mathrm{ml}$ of phosphate buffer saline (PBS). Samples were homogenized using a meat grinder under aseptic conditions.

\section{Isolation and identification of $P$. aeruginosa}

Two hundred meat samples were cultured into cetrimide agar, the plates were incubated aerobically at $37{ }^{\circ} \mathrm{C}$ for $24 \mathrm{~h}$. The putative colonies were examined for their colonial morphology and microscopically according to Quinn et al. [14], the purified isolates of $P$. aeruginosa were finally confirmed with a Vitek 2 system (bioMe'rieux) which is rapid and reliable identification method.

\section{Phenotypic detection of ESBL by double-disk synergy test method (DDST)}

ESBL production in $P$. aeruginosa was identified by the double disk synergy test (DDST) as described by Jarlier
[15]. Mueller-Hinton agar was inoculated with standardized inoculum (corresponding to 0.5 McFarland tube) using a sterile cotton swab. An Augmentin (20 $\mu \mathrm{g}$ amoxicillin and $10 \mu \mathrm{g}$ of clavulanic acid-AMC) disk was inserted in the center of the plate and test disks of 3rd generation cephalosporins (ceftazidime-CAZ $30 \mu \mathrm{g}$, ceftriaxone-CRO $30 \mu \mathrm{g}$, cefotaxime-CTX $30 \mu \mathrm{g}$ ) and aztreonam (ATM $30 \mu \mathrm{g}$ ) disks were placed at $20 \mathrm{~mm}$ distance (center to center) from the amoxicillin clavulanic acid disk. The plate was incubated overnight at $37^{\circ} \mathrm{C}$. Enhancement of the zone of inhibition of any one of the four drug disks toward amoxicillin-clavulanic acid suggested the presence of extended-spectrum beta-lactamases.

Escherichia coli 25922 was used as a negative control for the ESBL and $P$. aeruginosa ATCC 27853 was used as a control strain for a positive ESBL.

\section{Antimicrobial susceptibility testing}

Antibiotic susceptibility tests were performed for ESBL producing $P$. aeruginosa isolates by using the standard disc diffusion method (Kirby-Bauer) on Mueller-Hinton agar plates. The standard procedures of the CLSI, 2015 and British Society for Antimicrobial Chemotherapy (BSAC) disc diffusion method were strictly followed $[16,17]$, accordingly the antimicrobial susceptibility of $P$. aeruginosa strains were tested against 11 antimicrobial drugs: aztreonam $(30 \mu \mathrm{g})$, ceftazidime $(30 \mu \mathrm{g})$, ceftriaxone $(30 \mu \mathrm{g})$, cefepime $(30 \mu \mathrm{g})$, amikacin $(30 \mu \mathrm{g})$, gentamicin $(10 \mu \mathrm{g})$, ciprofloxacin $(5 \mu \mathrm{g})$, rifamycin $(30 \mu \mathrm{g})$, imipenem $(10 \mu \mathrm{g})$, meropenem $(1 \mu \mathrm{g})$ and sulphamethoxazole/trimethoprim $(25 \mu \mathrm{g})$. E. coli ATCC 25922 and $P$. aeruginosa ATCC 27853 were used as quality controls.

\section{DNA extraction}

The whole genomic DNA from ESBL resistant $P$. aeruginosa strains totaling 21 was extracted using QIAamp Mini Kit (QIAGEN, Hombrechtikon, Switzerland) according to the manufacturer's instructions.

\section{Molecular detection of ESBL-encoding genes}

PCRs for detection of the $b l a_{\mathrm{PER}-1}, b l a_{\mathrm{CTX}-\mathrm{M}}, b l a_{\mathrm{SHV}}$ and $b l a_{\mathrm{TEM}}$ genes. Specific primers for amplifying the selected genes by PCR are shown in Table 1.

The reaction mixture consisted of $25 \mu$ l Platinum ${ }^{\mathrm{TM}}$ Hot Start PCR Master Mix (Invitrogen $^{\mathrm{TM}}$ ), $1 \mu$ l DNA extract, $0.5 \mu \mathrm{l}$ of each primer in the concentration of (20 pmol) and nuclease free water up to $50 \mu \mathrm{l}$. The cycling conditions included denaturation for $10 \mathrm{~min}$ at $95{ }^{\circ} \mathrm{C}$, amplification for 30 cycles of $30 \mathrm{~s}$ at $95{ }^{\circ} \mathrm{C}, 1 \mathrm{~min}$ at $55^{\circ} \mathrm{C}$, and $1 \mathrm{~min}$ at $72{ }^{\circ} \mathrm{C}$, and extension for $10 \mathrm{~min}$ at $72{ }^{\circ} \mathrm{C}$. The PCR products were resolved by electrophoresis on $1.5 \%(\mathrm{wt} / \mathrm{vol}$ ) agarose gels (QIAGEN, Hombrechtikon, Switzerland). 
Table 1 Primers used for detection of resistance genes

\begin{tabular}{|c|c|c|c|}
\hline Target gene & Primer sequence $\left(5^{\prime}-3^{\prime}\right)$ & Product size (bp) & References \\
\hline \multirow[t]{2}{*}{$b l a_{\text {PER-1 }}$} & F: ATGAATGTCATTATAAAAGC & 926 & [18] \\
\hline & R:TTAATTTGGGCTTAGGG & & \\
\hline \multirow[t]{2}{*}{$b l a_{\text {CTX-M }}$} & F: GCGATGGGCAGTACCAGTAA & 392 & \\
\hline & R:TTACCCAGCGTCAGATTCCG & & \\
\hline \multirow[t]{2}{*}{$b l a_{\mathrm{SHV}}$} & F:TCAGCGAAAAACACCTTG & 472 & [19] \\
\hline & R: TCCCGCAGATAAATCACCA & & \\
\hline \multirow[t]{2}{*}{$b / a_{\mathrm{TEM}}$} & F: ATGAGTATTCAACATTTCCG & 861 & [20] \\
\hline & R:TTACCAATGCTTAATCAGTGAG & & \\
\hline
\end{tabular}

One uni plex PCR for detection of bla $a_{\mathrm{TEM}}$ gene and two multiplex PCR were conducted for the $\left(b / a_{\mathrm{PER}-1}\right.$ and $\left.b / a_{\mathrm{CTX}-\mathrm{M}}\right)$ and another one for $\left(b / a_{\mathrm{SHV}}\right)$ gene

\section{Results}

Isolation and identification of $P$. aeruginosa

Forty-five isolates (22.5\%) from meat samples of 200 camels were produced characteristic growth features of Pseudomonas species on the cetrimide agar medium. The isolates were obtained as one specific colony per camel meat sample. The isolates were confirmed as by Vitek 2 system (bioMe'rieux).

\section{Phenotypic detection of ESBL by double-disk synergy test method (DDST)}

Phenotypic detection of ESBL by DDST revealed that 21 $P$. aeruginosa isolates. Accordingly, a total percentage of ESBL was detected in overall, 45\% (21/45) from camel meat isolates.

\section{Antimicrobial susceptibility testing}

The results of the antimicrobial susceptibility testing for the 21 ESBL $P$. aeruginosa shows a high-level resistance (100\%) to ceftazidime, ceftriaxone and rifampicin followed by cefepime $(95.2 \%)$ and aztreonam $(76.1 \%)$. The susceptibilities of the isolates to meropenem, amikacin, imipenem, gentamicin and ciprofloxacin were 85.8, 81.0, 76.2, 71. 4 and 66.7 respectively (Table 2 ).

\section{Molecular detection of ESBL-encoding genes}

PCR screening of genes encoding ESBL revealed the amplification of $b l a_{\mathrm{PER}-1}, b l a_{\mathrm{CTX}-\mathrm{M}}, b l a_{\mathrm{SHV}}$ and $b l a_{\mathrm{TEM}}$ genes in all tested isolates except three isolates coded $\mathrm{p}-4$, -11 , and -18 did not harbor any of ESBL genes (Table 3).

Furthermore, eight out of 21 ESBL-positive isolates had the $b l a_{\mathrm{CTX}-\mathrm{M}}(38 \%)$, seven had $b l a_{\mathrm{SHV}}$ gene (33.3), and six carried $b l a_{\mathrm{TEM}}$ and $b l a_{\mathrm{PER}}$ genes (28.5).

\section{Discussion}

Extended-spectrum beta lactamase-producing bacteria are one of the fastest emerging resistance problems worldwide. ESBL-producing bacteria were observed in human medical practice, the observation of these
Table 2 Antibiotic resistance pattern of 21 Pseudomonas aeruginosa isolates

\begin{tabular}{lcl}
\hline Antibiotic & No (\%) resistant & No (\%) sensitive \\
\hline Amikacin $(30 \mu \mathrm{g})$ & $4(19.0)$ & $17(81.0)$ \\
Imipenem $(10 \mu \mathrm{g})$ & $5(23.8)$ & $16(76.2)$ \\
Gentamicin $(10 \mu \mathrm{g})$ & $6(28.5)$ & $15(71.4)$ \\
Ciprofloxacin $(5 \mu \mathrm{g})$ & $7(33.3)$ & $14(66.7)$ \\
Sulphamethoxazole/trimethoprim & $8(38.0)$ & $13(61.9)$ \\
$\quad(25 \mu \mathrm{g})$ & & \\
Rifampicin $(30 \mu \mathrm{g})$ & $21(100)$ & - \\
Ceftriaxone $(30 \mu \mathrm{g})$ & $21(100)$ & - \\
Cefepime $(30 \mu \mathrm{g})$ & $20(95.2)$ & $1(4.7)$ \\
Aztreonam $(30 \mu \mathrm{g})$ & $15(76.1)$ & $6(28.5)$ \\
Meropenem $(1.0 \mu \mathrm{g})$ & $3(14.2)$ & $18(85.8)$ \\
Ceftazidime $(30 \mu \mathrm{g})$ & $21(100)$ & - \\
\hline
\end{tabular}

bacteria in companion animals and the increase in livestock has initiated monitoring studies concentrating on livestock $[13,21]$.

Livestock may be an important vehicle for the community-wide dissemination of antimicrobial-resistant Enterobacteriaceae, also P. aeruginosa especially ESBLproducing type isolates have been found in increasing numbers in food-producing animals $[9,10,22]$.

Accordingly to the hypothesis that animals might become infection sources or even natural persistent sources acting as risky reservoirs of infection leading to the spread of these bacteria specifically multidrug resistant types in community [23]. There are essential needs for monitoring or surveillance studies incorporating veterinary medicine to identify transmissible pathogens to human and its risk factors.

The dromedary camel is a good source of meat, especially in areas where the climate adversely affects the performance of other meat animals. This is because of the unique physiological characteristics of camels [24]. The interest for camel meat seems by all accounts to be expanded because of wellbeing reasons, as it contains 
Table 3 ESBL resistance genes percent and antibiotic pattern of multiple drug resistant strains

\begin{tabular}{|c|c|c|c|c|c|c|}
\hline \multirow[t]{2}{*}{ Isolates } & \multicolumn{4}{|c|}{ Resistance gene pattern } & \multirow[t]{2}{*}{ Antimicrobial resistance } & \multirow[t]{2}{*}{ Antibiotic pattern } \\
\hline & $b l a_{\mathrm{PER}-1}$ & $b l a_{\mathrm{CTX}-\mathrm{M}}$ & $b l a_{\mathrm{sHV}}$ & $b l a_{\mathrm{TEM}}$ & & \\
\hline$P-1$ & & + & & + & CAZ, CRO, RD, FEP, ATM, AK, CN, CIP & MDR \\
\hline$P-2$ & + & + & + & & $C A Z, C R O, R D, F E P, A T M, M E M$ & MDR \\
\hline$P-3$ & & + & & + & $C A Z, C R O, R D, F E P, A T M, C I P$ & MDR \\
\hline$P-4$ & & & & & $C A Z, C R O, R D, F E P, A T M, C N$ & MDR \\
\hline$P-5$ & & + & & & $C A Z, C R O, R D, F E P, I P M$ & MDR \\
\hline$P-6$ & + & & & & $C A Z, C R O, R D, F E P, A T M, S X T$ & MDR \\
\hline$P-7$ & & + & + & & $C A Z, C R O, R D, F E P, A T M, I P M$ & MDR \\
\hline$P-8$ & & & + & + & $C A Z, C R O, R D, F E P, A T M, A K, C I P$ & MDR \\
\hline$P-9$ & + & & + & & CAZ, CRO, RD, FEP, ATM, MEM, CIP, SXT & MDR \\
\hline$P-10$ & + & & & & $C A Z, C R O, R D, F E P, C N, C I P$ & MDR \\
\hline$P-11$ & & & & & $C A Z, C R O, R D, F E P, A T M, C I P$ & MDR \\
\hline$P-12$ & & & & + & $C A Z, C R O, R D, F E P, A K, C I P$ & MDR \\
\hline$P-13$ & + & + & & & $C A Z, C R O, R D, F E P, C N$ & MDR \\
\hline$P-14$ & & & + & & CAZ, CRO, RD, FEP, IPM, SXT & MDR \\
\hline$P-15$ & & & & + & $C A Z, C R O, R D, F E P, A K, C N$ & MDR \\
\hline$P-16$ & & + & & & CAZ, CRO, RD, FEP, ATM, SXT & MDR \\
\hline$P-17$ & & + & + & & CAZ, CRO, RD, FEP, ATM, SXT & MDR \\
\hline$P-18$ & & & & & $C A Z, C R O, R D, F E P, I P M, C N$ & MDR \\
\hline$P-19$ & & & & + & $C A Z, C R O, R D, F E P, S X T$ & MDR \\
\hline$P-20$ & + & & & & CAZ, CRO, RD, FEP, ATM, IPM, SXT & MDR \\
\hline$P-21$ & & & + & & CAZ, CRO, RD, MEM, SXT & MDR \\
\hline$\%$ & $(6 / 21) 28.5$ & $(8 / 21) 38$ & $(7 / 21) 33.3$ & $(6 / 21) 28.5$ & & \\
\hline
\end{tabular}

MDR Multiple drug resistant

less fat and in addition less cholesterol and generally high polyunsaturated unsaturated fats than other animal's meat [25].

To the best of our knowledge, this is the first time that an attempt has been made to determine ESBL $P$. aeruginosa resistance in camel meat. In this study, the prevalence of $P$. aeruginosa in camel was determined about $22.5 \%(45 / 200)$. This percent is so higher to the encountered investigations on fish and cow in Switzerland and Nigeria $[9,26]$. Even though $P$. aeruginosa is ubiquitous, the prevalence of its isolation among camel isolates in this study was lower compared to the presence rate of $E$. coli that isolated from camel in Saudi Arabia with 26.0\% [27].

Class A (ESBLs) are typically identified in P. aeruginosa isolates and showing resistance to the extended-spectrum cephalosporin (ESCs) [28], this resistance is often due to the production of $\beta$-lactamases. Clinically, ESBLs are generally encoded by plasmid-mediated bla genes; three major clinically relevant $\beta$-lactamase genes are bla ${ }_{\mathrm{SHV}}, b l a_{\mathrm{TEM}}$ and $b l a_{\mathrm{CTX}-\mathrm{M} 2,4}[29]$.

The total percentage of ESBL producing $P$. aeruginosa was $45 \%(21 / 45)$ from camel meat isolates by DDST, accordingly, the most frequently $\beta$-lactamase-genes detected in this isolates were $b l a_{\mathrm{CTX}-\mathrm{M}}(38 \%)$, followed by $b l a_{\mathrm{SHV}}(33.3 \%)$ and $b l a_{\mathrm{TEM}}, b a l_{\mathrm{PER}-1}(28.5 \%)$.

CTX-M enzymes have now become the most widespread type of ESBL worldwide and represent the wide dissemination of particular plasmids or bacterial clones [30]. On the other hand, bla $a_{\mathrm{PER}-1}$ were found to be the most prevalent type of $\beta$-lactamase-encoding genes in Acinetobacter baumannii in Egypt [31] and this suggests the horizontal transfer of this gene.

In the present study antibiogram of ESBL producing $P$. aeruginosa showed high-level resistance (100\%) to ceftazidime, ceftriaxone and rifampicin followed by cefepime (95.2\%) and aztreonam (76.1\%).The susceptibilities of the isolates to meropenem, amikacin, imipenem, gentamicin, ciprofloxacin and amikacin were 85.8, 81.0, $76.2,71.5$ and $67 \%$ respectively (Table 2 ).

Pseudomonas aeruginosa and other gram negative bacteria with ESBLs contain other $\beta$-lactamases that makes difficult the phenotypic detection of ESBL [32], this issue need further investigation.

Many investigators focus on MDR $P$. aeruginosa from human. $P$. aeruginosa are multi-drug resistant to amikacin $(17.25 \%)$, ciprofloxacin $(27.59 \%)$, ceftriaxone varied from 51.00 to $73.00 \%$ and all the strains were susceptible 
to imipenem (20.69\%) [33]. High resistance to aminoglycosides had been reported in Malaysia [34]. Similarly higher rates of resistance to fluoroquinolones such as ciprofloxacin (40.5\%) had been reported in a study done in India. Lesser rate of resistance to ceftriaxone (40\%) had been reported in Andhra Pradesh, India [35].

The presence of high resistance profile by camel $P$. aeruginosa isolates my attributed antibiotics used in management of this animals or natural resistance of camel that suites it as a risk reservoir for such pathogens.

\section{Conclusion}

The present study demonstrates, for the first time in Egypt, the presence a high rate of ESBL-P. aeruginosa in camels, The abundance MDR $P$. aeruginosa from camel meat in this study suggests a potential risk of human susceptibility to such pathogen group which remodels the epidemiology of antibiotic resistance. Urgent control measures are necessary to be applied to restrict the continuous abuse of antibiotics, especially in livestock production.

\begin{abstract}
Abbreviations
ESBL: extended-spectrum beta-lactamase; MBL: metallo- $\beta$-lactamases; DDST: double disk synergy test; AST: antimicrobial susceptibility testing; PCR: polymerase chain reaction; MDR: multiple-drug-resistant; HGT: horizontal gene transfer; DDST: double-disk synergy test method; CLSI: the National Committee for Clinical Laboratory Standards; CAZ: ceftazidime; AK: amikacin; CRO: ceftriaxone; FEP: cefepime; ATM: aztreonam; MEM: meropenem; CIP: ciprofloxacin; SXT: sulphamethoxazole/trimethoprim; IPM: imipenem; CN: gentamicin; RD: rifampicin.
\end{abstract}

\section{Authors' contributions}

All authors contributed to the collection of samples, isolation of strains, performing the microbiological examinations, antimicrobial susceptibility testing and molecular detection of target genes, analysis and interpretation of the data as well as writing the manuscript. All authors read and approved the final manuscript.

\section{Author details}

${ }^{1}$ Department of Microbiology, Faculty of Veterinary Medicine, Cairo University, PO Box 12211, Giza, Egypt. ${ }^{2}$ Department of Zoonoses, Faculty of Veterinary Medicine, Cairo University, PO Box 12211, Giza, Egypt. ${ }^{3}$ Department of Microbiology and Immunology, National Research Centre, Giza, Egypt.

\section{Acknowledgements}

Not applicable.

\section{Competing interests}

The authors declare that they have no competing interests.

\section{Availability of data and materials}

All data generated or analysed during this study are included in this published article.

\section{Ethics approval and consent to participate}

The study was conducted according to ethical guidelines approved by Faculty of Veterinary Medicine, Cairo University. There were no experiments applied on human participants, as all samples were collected from abattoirs directly after slaughtering camels.

\section{Funding}

The authors declare that they did not have any funding source or grant to support their research work.

Received: 11 February 2017 Accepted: 28 March 2017

Published online: 31 March 2017

\section{References}

1. Strauß LM, Dahms C, Becker K, Kramer A, Kaase M, Mellmann A. Development and evaluation of a novel universal $\beta$-lactamase gene subtyping assay for bla $a_{\mathrm{SH},}, \mathrm{b} a_{\mathrm{TEM}}$ and bla $a_{\mathrm{CTX}-\mathrm{M}}$ using clinical and livestock-associated Escherichia coli. J Antimicrob Chemother. 2015;70(3):710-5.

2. Kidd TJ, Ritchie SR, Ramsay KA, Grimwood K, Bell SC, Rainey PB. Pseudomonas aeruginosa exhibits frequent recombination, but only a limited association between genotype and ecological setting. PLOS ONE. 2012;7(9):e44199.

3. Poonsuk K, Chuanchuen R. Contribution of the MexXY multidrug efflux pump and other chromosomal mechanisms on aminoglycoside resistance in Pseudomonas aeruginosa isolates from canine and feline infections. J Vet Med Sci. 2012;74(12):1575-82.

4. Salomonsen CM, Themudo GE, Jelsbak L, Molin S, Høiby N, Hammer AS. Typing of Pseudomonas aeruginosa from hemorrhagic pneumonia in mink (Neovison vison). Vet Microbiol. 2013;163(1):103-9.

5. Breidenstein EB, de la Fuente-Núñez $C$, Hancock RE. Pseudomonas aeruginosa: all roads lead to resistance. Trends Microbiol. 2011;19(8):419-26.

6. Tavajjohi Z, Moniri R, Khorshidi A. Detection and characterization of multidrug resistance and extended-spectrum-beta-lactamase-producing (ESBLS) Pseudomonas aeruginosa isolates in teaching hospital. Afr J Microbiol Res. 2011;5(20):3223-8.

7. Miko A, Pries K, Schroeter A, Helmuth R. Molecular mechanisms of resistance in multidrug-resistant serovars of Salmonella enterica isolated from foods in Germany. J Antimicrob Chemother. 2005;56(6):1025-33.

8. Schwaiger K, Huther S, Hölzel C, Kämpf P, Bauer J. Prevalence of antibioticresistant enterobacteriaceae isolated from chicken and pork meat purchased at the slaughterhouse and at retail in Bavaria, Germany. Int J Food Microbiol. 2012;154(3):206-11.

9. Odumosu BT, Ajetunmobi O, Dada-Adegbola H, Odutayo I. Antibiotic susceptibility pattern and analysis of plasmid profiles of Pseudomonas aeruginosa from human, animal and plant sources. SpringerPlus. 2016;5(1):1381.

10. Zurfluh K, Hindermann D, Nüesch-Inderbinen M, Poirel L, Nordmann $P$, Stephan R. Occurrence and features of chromosomally encoded carbapenemases in gram-negative bacteria in farm animals sampled at slaughterhouse level. Schweiz Arch Tierheilkd. 2016;158(6):457-60.

11. Ismail M, El-Deen NE, El-Hariri M. Bacteriological examination of respiratory tract of apparently healthy camels in Egypt. Int J. 2014;5(1):65-8.

12. Fadlelmula A, Al-Hamam NA, Al-Dughaym AM. A potential camel reservoir for extended-spectrum $\beta$-lactamase-producing Escherichia coli causing human infection in Saudi Arabia. Trop Anim Health Prod. 2016;48(2):427-33.

13. Smet A, Martel A, Persoons D, Dewulf J, Heyndrickx M, Herman L, Haesebrouck F, Butaye P. Broad-spectrum $\beta$-lactamases among Enterobacteriaceae of animal origin: molecular aspects, mobility and impact on public health. FEMS Microbiol Rev. 2010;34(3):295-316.

14. Quinn PJ, Carter ME, Markey B, Carter GR. Enterobacteriaceae. Clinical veterinary microbiology. London: Wolfe Publishing; 1994. p. 209-36.

15. Jarlier V, Nicolas MH, Fournier G, Philippon A. Extended spectrum $\beta$-lactamases conferring transferable resistance to newer $\beta$-lactam agents in Enterobacteriaceae: hospital prevalence and susceptibility patterns. Rev Infect Dis. 1988;10:867-78.

16. Clinical and Laboratory Standards Institute (CLSI). M100-S25 Performance standards for antimicrobial susceptibility testing: 25th informational supplement. Wayne: CLSI; 2015

17. Andrews JM, for the BSAC Working Party on Susceptibility Testing. BSAC standardized disc susceptibility testing method (version 8). J Antimicrob Chemother. 2009;64:454-89. 
18. Neyestanaki DK, Mirsalehian A, Rezagholizadeh F, Jabalameli F, Taherikalani M, Emaneini M. Determination of extended spectrum betalactamases, metallo-beta-lactamases and AmpC-beta-lactamases among carbapenem resistant Pseudomonas aeruginosa isolated from burn patients. Burns. 2014;40(8):1556-61.

19. M'Zali FH, Gascoyne-Binzi DM, Heritage J, Hawkey PM. Detection of mutations conferring extended-spectrum activity on SHV $\beta$-lactamases using polymerase chain reaction single strand conformational polymorphism (PCR-SSCP). J Antimicrob Chemother. 1996;37(4):797-802

20. Celenza G, Pellegrini C, Caccamo M, Segatore B, Amicosante G, Perilli M. Spread of blaCTX-M-type and blaPER-2 $\beta$-lactamase genes in clinical isolates from Bolivian hospitals. J Antimicrobl Chemother. 2006;57(5):975-8.

21. Ewers C, Grobbel M, Bethe A, Wieler LH, Guenther S. Extended-spectrum beta-lactamases-producing gram-negative bacteria in companion animals: action is clearly warranted. Berl Munch Tierarztl Wochenschr. 2011;124(3/4):4-101.

22. Mir RA, Weppelmann TA, Johnson JA, Archer D, Morris JG Jr, Jeong KC. Identification and characterization of cefotaxime resistant bacteria in beef cattle. PLoS ONE. 2016;11(9):e0163279.

23. Watkins RR, Bonomo RA. Overview: global and local impact of antibiotic resistance. Infect Dis Clin North Am. 2016;30(2):313-22.

24. Kadim IT, Mahgoub O, Purchas RW. A review of the growth, and of the carcass and meat quality characteristics of the one-humped camel (Camelus dromedaries). Meat Sci. 2008;80(3):555-69.

25. Abdelhadi OM, Babiker SA, Bauchart D, Listrat A, Rémond D, Hocquette $J F$, Faye B. Effect of gender on quality and nutritive value of dromedary camel (Camelus dromedarius) longissimus lumborum muscle. J Saudi Soc Agri Sci. 2015. doi:10.1016/j.jssas.2015.08.003.

26. Boss R, Overesch G, Baumgartner A. Antimicrobial resistance of Escherichia coli, enterococci, Pseudomonas aeruginosa, and Staphylococcus aureus from raw fish and seafood imported into Switzerland. J Food Prot. 2016;79(7):1240-6.
27. Fadlelmula A, Al-Hamam NA, Al-Dughaym AM. A potential camel reservoir for extended-spectrum $\beta$-lactamase-producing Escherichia coli causing human infection in Saudi Arabia. Trop Anim Health Prod. 2016;48(2):427-33.

28. Fadlelmula A, Al-Hamam NA, Al-Dughaym AM. A potential camel reservoir for extended-spectrum $\beta$-lactamase-producing Escherichia coli causing human infection in Saudi Arabia. Trop Anim Health Prod. 2016;48(2):427-33.

29. Bush K. The ABCD's of $\beta$-lactamase nomenclature. J Infect Chemother. 2013;19(4):549-59.

30. Cantón R, Novais A, Valverde A, Machado E, Peixe L, Baquero F, Coque TM Prevalence and spread of extended-spectrum $\beta$-lactamase-producing Enterobacteriaceae in Europe. Clin Microbiol Infect. 2008;14(s1):144-53.

31. Al-Agamy MH, Khalaf NG, Tawfick MM, Shibl AM, El Kholy A. Molecular characterization of carbapenem-insensitive Acinetobacter baumannii in Egypt. Int J Infect Dis. 2014;22:49-54.

32. Manchanda V, Singh NP. Occurrence and detection of AmpC betalactamases among gram-negative clinical isolates using a modified three-dimensional test at Guru Tegh Bahadur Hospital, Delhi, India. J Antimicrob Chemother. 2003;51:415-8.

33. Chander A, Raza MS. Antimicrobial susceptibility patterns of Pseudomonas aeruginosa clinical isolates at a tertiary care hospital in Kathmandu, Nepal. Asian J Pharm Clin Res. 2013;6(3):235-8.

34. Fazlul MK, Zaini MZ, Rashid MA, Nazmul MH. Antibiotic susceptibility profiles of clinical isolates of Pseudomonas aeruginosa from Selayang Hospital, Malaysia. Biomed Res. 2011;22(3):263.

35. Ramana BV, Chaudhury A. Antibiotic resistance pattern of Pseudomonas aureuginosa isolated from healthcare associated infections at a tertiary care hospital. J Sci Soc. 2012;39(2):78.

\section{Submit your next manuscript to BioMed Central and we will help you at every step:}

- We accept pre-submission inquiries

- Our selector tool helps you to find the most relevant journal

- We provide round the clock customer support

- Convenient online submission

- Thorough peer review

- Inclusion in PubMed and all major indexing services

- Maximum visibility for your research

Submit your manuscript at www.biomedcentral.com/submit
O Biomed Central 